Article

\title{
Lessons Learned from Developing a New Distance-Learning Masters Course in the Green Economy
}

\author{
Adrian C. Newton *, Elena Cantarello, Chris Shiel and Kathy Hodder \\ Faculty of Science and Technology, Bournemouth University, Fern Barrow, Talbot Campus, \\ Poole BH125BB, UK; E-Mails: ecantarello@bournemouth.ac.uk (E.C.); \\ cshiel@bournemouth.ac.uk (C.S.); khodder@bournemouth.ac.uk (K.H.) \\ * Author to whom correspondence should be addressed; E-Mail: anewton@bournemouth.ac.uk; \\ Tel.: +44-(0)-1202-965-670.
}

Received: 5 February 2014; in revised form: 8 April 2014 / Accepted: 9 April 2014 /

Published: 15 April 2014

\begin{abstract}
It is widely recognised that for the green economy to develop successfully, new educational curricula will be required to help professionals develop appropriate knowledge and skills. Relatively few university courses have been developed to date that explicitly focus on the green economy, reflecting its recent origins. Here we present the lessons learned from developing and implementing a new Masters course in the green economy, at Bournemouth University in the UK. The most significant challenges were institutional barriers, such as different departmental policies and procedures and decentralised budget strategies, which inhibited the cross-departmental collaboration desired for interdisciplinarity. Uncertainty about the future development of the green economy and its value as a concept, among both teaching staff and prospective students, presented a further challenge. In addition, the development of an appropriate curriculum for green economy courses has received little attention previously. Here, we present an overview of the curriculum developed for this Masters-level course, and, based on our experience, we demonstrate how the challenges in developing such a course can successfully be overcome.
\end{abstract}

Keywords: distance learning; sustainability; sustainable development; MSc; education 


\section{Introduction}

The green economy has recently become the focus of increasing policy interest, at both national and international scales. This is illustrated by the development of many national strategies for the green economy, supported by a range of international platforms, partnerships and other initiatives [1,2]. Most significantly, the green economy was included as one of two principal themes for the $2012 \mathrm{UN}$ Conference on Sustainable Development $(\mathrm{Rio}+20)$ [3], which led to the production of a large number of position papers and background reports on the topic [4]. This growth in interest can be attributed to the perceived value of the green economy for concurrently addressing multiple global problems, including the recent financial crisis, increasing food prices, widespread poverty, and the environmental issues of anthropogenic climate change and biodiversity loss [5,6]. However, the green economy should not be viewed purely as an intergovernmental initiative. It has also attracted great interest from the business community [7-11] and the international media. It can also be considered as a social movement, with many civil society organisations encouraging grass-roots innovation [6], and as an environmentalist or social justice issue with links to Green politics [12].

Although there is a lack of consensus about precisely how the green economy should be defined, it is generally agreed that it should improve human well-being and reduce inequality, while reducing human impacts on the environment [6]. Although for some commentators the green economy primarily relates to green technology and renewable energy (e.g., see [13]), most definitions or sets of guiding principles that have been proposed are much broader. Typically they encompass the social, economic and environmental elements of sustainable development, often with a strong emphasis on social aspects [14]. Areas of contention include whether or not the green economy is consistent with economic growth, and whether or not it should explicitly refer to the concept of environmental limits or carrying capacity [6].

Despite some ambiguity about what the green economy might entail in practice, there is general agreement that education has an important role to play in helping to bring it about [15]. For example, the United Nations Environment Programme (UNEP) [16] highlights the need for revised educational curricula and training programmes to promote cleaner processes and systems, eco-design, products and services, and to help provide the large numbers of skilled professionals that will be required. UNEP [16] also note the particular need for education in the so-called STEM (science, technology, engineering, and mathematics) disciplines; a lack of such skills could potentially impede efforts towards green economic development. Similarly, the United Nations Environment Management Group (UNEMG) [17] highlight the need for both technical and vocational education and training to generate knowledge for innovation, to help alleviate poverty, and to encourage changes in individual behaviour, attitudes, lifestyles, consumption and production patterns. A business perspective is provided by the International Chamber of Commerce (ICC) [18], which again emphasizes the importance of education for the "operationalization" of the green economy, particularly in STEM disciplines and inter-disciplinarity, human and natural capital, sustainable livelihoods and capacity building. The need for a future emphasis on education is also noted in the Rio +20 outcome document, The Future We Want [19].

Here we describe a new Masters-level course in the green economy, which was developed to help meet these educational needs. The Master of Science (MSc) Green Economy course was developed by Bournemouth University in the UK in 2010-2011, and has run annually since then. In this paper, we 
describe how the course was developed and implemented, with the aim of examining the challenges that were encountered and how these were overcome. Rather than offering a template or blueprint for other such courses, our aim here is to identify the principal lessons learned from developing a postgraduate taught course that explicitly focuses on the green economy. These lessons are presented in the hope that others planning to develop an educational offering on this theme, at whatever level, might benefit from our experience.

\section{Context for Course Development}

Bournemouth University (BU) was inaugurated in 1992, and currently possesses 650 academic staff, with around 1100 postgraduate awards and 3200 undergraduate awards given per year. Over 17,000 students currently attend the university, including 1800 from non-EU countries. The MSc Green Economy was developed by staff within the School of Applied Sciences, which forms one of six academic departments that comprise BU.

The impetus for developing this new course came primarily from three drivers. First, local Government within the region where BU is located (Bournemouth and Poole, in the English county of Dorset) had recently identified development of the green economy as a local strategic priority, in accordance with national government policy [20]. The course was therefore partly designed to strengthen local and national capacity for green economic development. Second, the course was designed to capitalise on the research strengths of the University in environmental science and other areas relevant to the course theme, including environmental law, business, tourism, sustainable design and technology. Third, the recent rapid growth of interest in the green economy among business and policy communities suggested that there may be emerging opportunities for individuals wishing to develop a career in this area. From the outset, the course was therefore explicitly designed to strengthen employability of participating students. In addition to these drivers, the course was developed against a backdrop of a recent national decline in the number of postgraduate students from the UK, coinciding with major reforms in how universities are funded and an economic downturn [21]. This MSc was therefore partly developed to diversify the portfolio of courses offered by BU, in a way that would be attractive to both UK and international clients.

In 2010, we conducted a programme of market research that indicated that no other MSc course existed that explicitly focused on the green economy. We identified 47 other MSc courses offered by UK Universities that offered material in a cognate area, such as renewable energy, sustainable development or environmental technology. Many additional courses with a related theme were found to be offered by institutions in other countries, although again, none explicitly focused on the green economy. Since 2010, a number of Masters-level courses with "green" in their title have been offered by other institutions, such as a Master in Green Management, Energy and Corporate Social Responsibility at the Università Bocconi, Italy; an MBA in Green Energy and Sustainable Businesses at the Università Bologna, Italy; and a Global Green MBA at the University of Haifa, Israel. The results of our market survey suggested that while many Universities offer courses relevant to the theme of sustainable development or renewable energy, few have so far taken the step of explicitly labelling them "green". 
While we interpreted the lack of competing green economy courses as an opportunity, it also represented a challenge. The market potential for courses on the green economy is untested and is therefore largely unknown. Institutions considering developing a course on this theme will wish to be confident that sufficient demand exists to ensure its financial viability. At the same time, prospective students will need to be confident that the title of their degree will both reflect their academic interests and strengthen their employability. As use of the term "green economy" has only recently become widespread, development of courses specifically on this theme represents a relatively high risk strategy. This might explain some apparent reticence among universities to change the title or focus of well-established courses on related themes, such as sustainable development.

A further key decision focused on provision of Masters-level education rather than alternatives, such as vocational qualifications or an undergraduate degree. It is clear that education at a wide range of different levels, strengthening a variety of skills, is required to support development of the green economy $[22,23]$. On the other hand, it is recognised that postgraduate qualifications provide higher level skills and subject-specific knowledge that are valued by employers; for example in the UK, unemployment rates for those holding a postgraduate qualification are lower than for those with only a first degree, and those holding a Masters-level qualification on average earn around 15\% more [21].

\section{Course Design and Delivery}

The most significant challenge in developing this course was defining an appropriate curriculum. As the green economy is a relatively new concept, relatively little attention has been given to identifying the knowledge and skills that might be required by prospective students, or what the core elements of a suitable curriculum might be. However, some commentators have suggested where national capacities may need to be strengthened to facilitate development of the green economy. For example, in this context UNEMG [17] identified green technologies, ecosystem services, green finance and green accounting, together with integrated resource management and eco-entrepreneurship. Similarly HM Government [23] suggested that in the UK, skills are needed to support resource efficiency, low carbon industry, climate resilience, and in managing natural assets.

Identification of an appropriate curriculum and learning approach can potentially be informed by experience in education for sustainable development, which has a more established tradition. This is considered in depth by Wals [24], in relation to the UN Decade of Education for Sustainable Development (ESD) (2005-2014). According to Wals [24], the nature of sustainability challenges requires integrative, problem-based and exploratory forms of learning that invite participants to be critical, creative and change-oriented. ESD should focus on holistic, integrative and critical ways of addressing sustainability challenges, involving approaches such as problem-based learning, multi-stakeholder social learning, interdisciplinary learning, action learning and critical thinking-based learning [24]. Ideally, universities engaged in ESD should themselves seek to be managed sustainably, enabling learning and acting to be integrated. Wals [24] also advocated placing students in a global context to address real-world corporate or industry sustainability challenges; use of holistic or systems-based approaches; and education in complexity, controversy and uncertainty.

Insights into an appropriate curriculum for a course on sustainable development can also be gained by referring to text books on this subject. For example, the text provided by Rogers et al. [25] includes 
chapters on global environmental issues, sustainable development indicators, environmental assessment and management, legislation and environmental law, social dimensions and policies, economics and valuation, international financial institutions and cooperation. While the content of other text books on sustainable development (e.g., [26-28]) differ in detail, their broad coverage is similar. The extent to which such texts could provide a suitable basis for a green economy curriculum depends on the relationship between the two concepts, an issue that is the focus of ongoing debate.

Given that sustainable development continues to be the overarching policy goal of the international community, some commentators have suggested that the green economy should essentially be seen as equivalent to it $[4,29]$. For others, however, the green economy carries a more distinctive meaning, which often focuses specifically on the fundamental changes that are required to ensure that economic systems are made more sustainable [30,31]. More specifically, while definitions of sustainable development tend to view environmental, social and economic components as of equal importance, some concepts of the green economy view the environment as being more fundamental, by underpinning the global economy rather than simply comprising an element of it [12,32]. A lack of sufficient emphasis on the environment has been identified as one of the main weaknesses of the concept of sustainable development [33].

Views on an appropriate composition of a green economy curriculum clearly depend on which definition or concept of the green economy is adopted, an issue that is currently contested [4]. However, it is striking that elements of a green economy on which there is broad consensus - such as carbon management, climate change, renewable energy and green technology-receive little (if any) mention in text books on sustainable development (e.g., [25-28]). Many of these texts focus on social science, and provide little coverage of environmental science or sustainability science. Currently, no text book is available that explicitly attempts to provide an overview of the green economy. For this reason, a new text book [6] was produced with this focus, based on the learning materials developed for the course described here. This book provides an overview of different definitions and principles of the green economy, and contrasting perspectives on how it should be implemented in practice, including its relationship to sustainable development. These areas of contention and debate are explicitly highlighted during the course, and students are encouraged to develop their own conception of what the green economy entails, through a process of critical evaluation and reflection.

Following the concept that the environment is of fundamental importance to the green economy [12,32], and following the recommendations of Mace [34], we grounded our course curriculum (Table 1) firmly within environmental science, focusing on the ecological processes that underpin sustainability. Following Wals [24], the curriculum also focused on holistic, integrative and critical ways of addressing sustainability challenges, involving problem-based and interdisciplinary learning, with an emphasis on critical thinking and use of systems-based approaches. Specifically, the course content was divided into six taught units:

- Frontiers in sustainability science

- Climate change and carbon management

- Sustainable development in practice

- Green technology and renewable energy

- Biodiversity and ecosystem services 
- Environmental law and social justice

It should be noted that the curriculum presented here (Table 1) offers just one among many possible alternative approaches to defining an appropriate content for a course on the green economy. However, this solution at least provides a broad overview of the principles on which the green economy is based, and an indication of how it might be achieved in practice.

Table 1. Outline of a potential curriculum for a Masters-level course on the green economy, based on the taught units of the MSc Green Economy offered at Bournemouth University, UK, but further developed as described by Newton and Cantarello [6].

\begin{tabular}{|c|c|}
\hline & \\
\hline $\begin{array}{l}\text { - Definition of the green economy } \\
\text { - Policy context } \\
\text { - Green economy versus sustainable development } \\
\text { - Neoclassical economics } \\
\text { - Ecological economics } \\
\text { - Green economics } \\
\text { - The economy and the environment } \\
\text { - Is the green economy a flawed idea? }\end{array}$ & $\begin{array}{l}\text { - Earth system science } \\
\text { - Understanding complex systems } \\
\text { - Resilience and tipping points } \\
\text { - Critical loads and vulnerability } \\
\text { - Planetary boundaries and ecological } \\
\text { - footprint analysis } \\
\text { - Environmental limits to economic growth } \\
\text { - Consumption } \\
\text { - } \text { Common property resources and the } \\
\text { Human behaviour and the green economy }\end{array}$ \\
\hline Climat & Biodi \\
\hline $\begin{array}{l}\text { - } \text { Global carbon cycle and carbon modelling } \\
\text { - Climate change and impacts of } \mathrm{CO}_{2} \text { emissions } \\
\text { - Climate change policy } \\
\text { - } \quad \text { Measuring and reporting GHGs } \\
\text { - The compliance and voluntary carbon markets } \\
\text { - } \quad \text { Adaptation and mitigation measures } \\
\text { - Trade-offs between carbon storage and other } \\
\text { ecosystem services }\end{array}$ & $\begin{array}{l}\text { - } \text { Global biodiversity crisis } \\
\text { - } \text { Ecosystem collapse } \\
\text { - } \text { Biodiversity and ecosystem function } \\
\text { - } \text { Ecosystem services } \\
\text { - } \text { Impluing nature } \\
\text { - } \text { Response options: sustainable use and } \\
\text { - } \text { protected areas } \\
\text { - } \text { Linking with the green economy }\end{array}$ \\
\hline logy and renewabie energy & ll law and social justice \\
\hline $\begin{array}{ll}\text { - } & \text { Types of renewable energy } \\
\text { - } & \text { Cost-effectiveness of renewable energy } \\
\text { - } & \text { Energy efficiency technologies } \\
\text { - } & \text { Green buildings } \\
\text { - } & \text { Green transport } \\
\text { - } & \text { Sustainable waste management } \\
\text { - } & \text { Emerging green technologies } \\
\text { - } & \text { Assessing the environmental impact of } \\
\text { - } & \text { green technology } \\
\end{array}$ & $\begin{array}{l}\text { - } \quad \text { What is environmental law? } \\
\text { - } \quad \text { Environmental values } \\
\text { - } \quad \text { Forms and sources of environmental law } \\
\text { - } \quad \text { Principles of environmental law } \\
\text { - International trade. } \\
\text { - } \quad \text { Social and environmental justice } \\
\text { - } \text { Globalisation } \\
\text { - Environmental justice in practice } \\
\text { - Environmental justice and indigenous peoples } \\
\text { - Environmental justice and gender }\end{array}$ \\
\hline
\end{tabular}


Table 1. Cont.

\begin{tabular}{|c|c|}
\hline The green economy in practice & Outlook for the green economy \\
\hline $\begin{array}{l}\text { - Sustainable agriculture } \\
\text { - Sustainable forest management } \\
\text { - Sustainable fisheries } \\
\text { - Sustainable water management } \\
\text { - Green urban development } \\
\text { - } \text { Green tourism } \\
\text { - Sustainable consumption and production } \\
\text { - } \quad \text { Green business } \\
\text { - Sustainability frameworks and approaches }\end{array}$ & $\begin{array}{l}\text { - } \quad \text { Some future trends } \\
\text { - } \text { Principles of the green economy } \\
\text { - } \text { Measuring progress } \\
\text { - } \text { Policy and governance } \\
\text { - } \text { Capital investment } \\
\text { - Employment } \\
\text { - } \quad \text { Economic growth } \\
\text { - } \text { Globalisation versus localisation }\end{array}$ \\
\hline
\end{tabular}

It is generally recognised that the green economy is a highly interdisciplinary topic, and therefore course materials were drawn from a range of disciplines, including ecological science, geography, social science, psychology, law and economics. Some subjects, such as economics and social science, were addressed in a cross-cutting way through their inclusion in multiple units, rather than through creation of subject-specific units. Environmental law and social justice were identified as essential course components, given their widespread recognition as key elements of the green economy [4,5]. The course also attempted to provide a foundation in scientific principles (for example in the Frontiers of Sustainability Science unit) together their practical application in the real world (for example in the Sustainable Development in Practice unit, which was largely drawn from real-world case studies).

The course was designed to be delivered entirely by distance learning. Although distance learning courses are now widespread, accounting for some $13 \%$ of all registered postgraduate students in the UK [21], this represented a novel approach for BU. This decision was taken to minimise the environmental impacts of the learning process, following the recommendation of Wals [24] that education on sustainability should integrate learning and acting. The vision of the course was to allow students anywhere in the world to study in their own homes, with all learning materials provided through a Virtual Learning Environment (VLE) hosted at BU. The course was also structured flexibly to allow students to study either full- or part-time, enabling learning to be combined with other activities such as employment. Three taught units are offered in each of two fifteen-week semesters, with each unit running for the full duration of the semester. Part-time students have a free choice of units within each semester, and the units can also be taken as individual accredited CPD units in any order over a period of up to five years. A focus on strengthening employability was further supported by another innovative feature of the course, namely the option of undertaking an extended professional placement and submitting a portfolio of work-based activities, in lieu of the more traditional research dissertation.

\section{Course Implementation}

The entire course is delivered by the VLE, structured around the six taught units. In each of these units, students are provided with electronic documents that provide an introduction to each topic, while explicitly encouraging reflective learning. Students are also provided with access to research publications from leading academic journals, and are required to critically evaluate the evidence presented within these, as a basis of their assignments. These materials deliberately focus on areas of 
debate or controversy, and of conflicting evidence, to expose students to complexity, controversy and uncertainty, as advocated by Wals [24]. Problem-based learning is supported through additional elements of their assignments, which focus on application of the knowledge gained to real-world problems, through use of a variety of different skills (e.g., conceptual modelling, scenario development, presentational skills, development of carbon management plans, etc.). The course material is also increasingly being supported by use of audio and video presentations. One-to-one support from staff is provided to each student, through provision of formative assessment, delivered through the VLE and via email and video link. This includes written feedback on all draft assignments, which is provided on a weekly basis. Students are required to undertake a two-part assignment for each unit, the first part of which requires short written answers to questions relating to the set reading material. The second part of each assignment focuses on project work, applying the knowledge gained to real-world practical problems. The students are also provided with an opportunity to research a topic of their choice in greater depth, through their dissertation or extended professional placement, which they are required to complete in addition to the taught units. To date, students have undertaken a very wide range of different projects towards their dissertations (Table 2).

Table 2. Selected examples of dissertation titles, illustrating the range and type of topics submitted for the research project or extended professional placement component of the course.

\begin{tabular}{|l|}
\hline Dissertation title \\
\hline Sustainable buildings, the way forward \\
\hline $\begin{array}{l}\text { Waste policy, the waste hierarchy, mitigation of greenhouse gas emissions and extended } \\
\text { marginal abatement cost- - the Malta case }\end{array}$ \\
\hline Transitioning small to medium sized organisations to a sustainable future \\
\hline Valuing ecosystem services and environmental capital in Dorset UK \\
\hline The effect of anthropogenic activities to wetland birds at Pagham Harbour, UK \\
\hline $\begin{array}{l}\text { Implementing green technology and renewables on a new development and oil } \\
\text { spill remediation }\end{array}$ \\
\hline Setting the scene from concept to completion for Citi Bank's New Energy Initiative \\
\hline $\begin{array}{l}\text { An investigation of the technologies and implementation of large-scale onshore wind } \\
\text { turbines and solar photovoltaics within the south-west of England }\end{array}$ \\
\hline An investigation of carbon foot printing tools available to small to medium sized businesses \\
\hline $\begin{array}{l}\text { The impact of microfinance on sustainability: A case study of the MFI Pamecas pairing } \\
\text { microfinance with microinsurance in Guédiawaye, Senegal }\end{array}$ \\
\hline $\begin{array}{l}\text { Incorporating ecosystem service valuation into marine spatial planning: The next } \\
\text { development in ecosystem-based marine management? }\end{array}$ \\
\hline Preparation of a Carbon Management Plan for Bridport Town Council \\
\hline SHEQ (Safety, Health, Environment and Quality) Project management \\
\hline Citi Green Team "Corporate initiatives towards becoming more sustainable": An evaluation \\
\hline $\begin{array}{l}\text { Developing strategic plans towards Bournemouth Borough Council's environmental and } \\
\text { sustainability goals }\end{array}$ \\
\hline The Poverty-Environment Initiative (PEI) of Lao PDR, UNDP-UNEP \\
\hline
\end{tabular}

Since its launch in the academic year 2011/2012, the course has attracted three cohorts of students, numbering 57 in total. The course is now annually meeting its recruitment target of 20-30 students per 
year. Of these, $70 \%$ elect to study part-time, highlighting the value of distance-learning courses such as this in enabling students to combine their studies with other activities, such as employment. More than one third of the students have been drawn from outside the UK, including Austria, Ireland, Italy, Lebanon, Germany, Spain, Switzerland and Malta. Some of the students have also taken the course while working overseas.

\section{Lessons Learned}

Developing new course provision is always a challenge; developing a course that addresses a relatively new concept, with an ambition to deliver entirely via an electronic medium, increases the layers of complexity and the challenges presented to the course team. In this section, we outline some of these challenges and the lessons that have been learned in developing and implementing the programme. First, the most significant barriers impeding development were institutional. Typically, university systems and processes are geared to full-time, face-to face modes of learning, which may need to be amended to offer distance-learning opportunities. As illustration, in our case the University regulations requiring students to be physically present when registering for a course had to be changed, to allow students studying remotely to register on-line.

However, the most significant institutional hurdle, experienced at the outset, was the ambition to achieve the desired degree of interdisciplinarity, through interdepartmental collaboration. The challenges of implementing interdisciplinary approaches to both research and education in universities are widely recognised [35-37]. Such challenges include a lack of resources to support interdisciplinary working, lack of supportive academic reward systems, contrasting academic cultures in different disciplines, different departmental policies and procedures, and decentralised budget strategies [38]. Although some universities have sought to overcome such institutional barriers through major departmental restructuring [39], these problems are still widespread. In our case, the problem of decentralized departmental budgets, together with different departmental policies, prevented development of the course in collaboration with staff in other departments (such as BU's Business School), as was originally envisaged. As a result, elements such as green procurement, entrepreneurship and business management had to be omitted from the course curriculum. Ultimately a degree of interdisciplinarity was achieved through creation of a multidisciplinary teaching team drawn from within a single department, which was subsequently strengthened by recruitment of a former staff member of the Business School.

Once the course concept and a programmes specification were developed, further institutional barriers were encountered through the course validation process, which each new course must undergo as part of standard quality assurance procedures. This included development of extensive course documentation, which was scrutinised separately both by internal and external panels. Such scrutiny increases when e-learning is deployed, and ironically led to an increase in the paperwork required. In our experience, the internal assessment process was the more challenging: some of our colleagues were unfamiliar with the concept of the green economy; some were not convinced of its value as a course theme; and there was some resistance to the development of a distance learning course, which represented a novel venture for our University. Some colleagues expressed concern about the quality of the learning experience that could be provided by virtual delivery. This experience highlights the 
need to build interest and engagement in education on the green economy among colleagues, before initiating the process of course development. We also had to invest substantial time and resources in building the academic and business case for the course.

We found that development of this course was a learning process for the educators and the institution, as well as for students. We found the lack of any clear guidance on designing an appropriate curriculum both challenging and stimulating. By developing novel courses of this nature, there is perhaps an opportunity to influence how the green economy will develop, both academically and in practice (e.g., see [6]). Our original vision of developing a "community of practice", with students learning by doing [24] and exchanging information with their peers, has not yet been fully realised, but will hopefully come with time. This partly reflects the difficulties inherent in a distance learning method of delivery, and the limitations this inevitably places on pedagogical approach [40], particularly with respect to group-based and peer-to-peer learning. However, it also reflects the fact that course development processes can be bureaucratic, which limits the time to develop innovative pedagogic approaches before the course first goes to market. Although students have been provided with one-to-one support from staff, and on-line discussion forums to interact with their peers, our development of group-based work is at an early stage. We are attempting to enhance this element with each iteration of the programme, but want to ensure that sufficient time is spent on developing the right "e-tivities" [41] in response to student feedback. Specifically, we are examining whether a more active approach to on-line learning will strengthen student engagement and enhance learning outcomes. Students are now being encouraged to pose problems through discussion forums, which are also serving as a vehicle for "reflection on action" [42], and action learning is being supported through dissertation projects. Some students have certainly missed the social interaction associated with traditional class-based teaching, but this can potentially be accommodated within a VLE. The potential for development of online learning environments that enable much more effective peer interaction is rapidly developing. For example, on the Future Learn platform [43], students can enter into peer debate, "like" and "follow" each other's posts in a manner comparable to popular social media such as Facebook and Twitter. Hence, we anticipate further development of the capacity to advance this aspect of course delivery.

Our experience provides evidence that there is a demand for education on the green economy, although the extent of this demand is unknown. Potentially, it could be very significant: a recent survey of 6000 new university entrants found that over $80 \%$ believe that sustainability skills are important for their future employment [44]. Our experience indicates that some students are very highly motivated to take advantage of the employment opportunities provided by the developing green economy, and are seeking educational opportunities to help them achieve this. Feedback from the students about the course has consistently been very positive, many of them recognising the unique learning opportunity that it provides. However, we have encountered some uncertainty among both actual and prospective students regarding where employment opportunities in the green economy currently exist, how the green jobs market might develop in future, and what precise skills will be needed. The extended professional placement element of our course is a particularly welcome feature, enabling students to strengthen their employability in this area. Such longitudinal integrated placements have proved effective in enhancing student self-efficacy beliefs and in developing professional identity [45]. During placements, some students have demonstrated significant leadership 
and have acted as agents of change within their institutions, supporting the transition towards a green economy. Gratifyingly, a number of graduates have since secured employment as green economy professionals, as a direct result of taking this course. However, we have identified the need to engage more closely with potential employers in the future, to increase our understanding of their evolving requirements for knowledge and skills. As well as the more traditional professional placement, such engagement could take the form of experiential field learning as used in the social sciences (e.g., [46]).

Despite the challenges encountered, the experience of developing this course has strengthened our belief that new educational resources and approaches focusing on the green economy are urgently needed. Many people are deeply concerned about environmental and social issues, and are keen to identify a positive contribution that they can potentially make to addressing global problems, while developing their careers. This applies both to people at the beginning of their careers and more established professionals. In our view, the green economy offers a positive vision of how to achieve this in practice, and this represents one of its main values as a concept. However, educational opportunities in the green economy are currently limited. In a recent review, the Higher Education Academy [47] noted that universities in the UK (as elsewhere) have been slow to engage with the green economy as a strategic issue, although there is growing recognition of the need for widespread curriculum reform to support 21 st century citizenship and employment. For example, increasing understanding of natural capital and its role as the basis of "green capitalism" are identified by Peters and Britez [15] as one of the greatest tasks currently facing education. For the green economy to develop successfully, there is a need for people who understand the complex linkages between the environment and the economy, and who can identify creative solutions to economic development that reduce human impacts on the environment. The development of education to meet this need requires innovation, and may require significant investment of time and resources. In our case, the educational and employment outcomes for the students concerned have undoubtedly justified such investments, and have been ample reward for our efforts.

\section{Conclusions}

While there is widespread recognition of the need for new educational opportunities to support development of the green economy, universities have generally been slow to respond to this need. Our experience, in developing a new course that explicitly focused on the green economy, suggests that significant barriers that limit such innovation can lie within universities themselves. The green economy is a relatively new concept, and many aspects of it are controversial [6]. Many academics, even those familiar with the discourse relating to sustainability, are unconvinced about the merits of the green economy as a concept, or how it is being incorporated into policy [48-50]. This may account for its relatively slow uptake in higher education. However, without appropriate curriculum development and educational reform, there is a risk that future generations of graduates could become disenfranchised from $21 \mathrm{st}$ century society and miss opportunities to become skilled "green" practitioners and entrepreneurs [44]. We believe that the controversy, uncertainty and complexity that characterise the green economy also provide an outstanding educational opportunity for students interested in critical, creative and change-oriented learning [24]. Our approach in developing this course has therefore focused on exposing students to a wide variety of different perspectives relating to 
the green economy, and encouraging them to develop their own ideas of how it should be implemented in practice, rather than promoting a single conception of what the green economy entails.

Higher education is itself currently undergoing a transformation, as illustrated by the recent rapid expansion in massive open online courses (MOOCs) [51]. With individual courses enrolling over 100,000 students, newly developed MOOCs are extending the global reach of higher education while generating substantial interest among learners [42]. Although MOOCs are not without criticism (course retention is typically low and pedagogy is sometimes questionable; e.g., [52]), given their relatively low environmental impacts, they might have a particular role to play in green economy education. Potentially, pedagogical problems associated with distance learning courses such as MOOCs can be addressed through appropriate design of learning materials and assignments, and through provision of tutor support [42]. For example, a focus on formative feedback rather than summative "end of course" testing is recommended by learning theorists, as it provides a basis for learning rather than simply delivering knowledge [52]. This is supported by our experience in developing the distance learning course described here, which provides one-to-one tutor support and formative feedback.

Potentially, the course described here could readily be developed into a MOOC, although such a development would likely encounter further institutional obstacles, as encountered in many other universities [53]. Other potential developments could involve expansion of the course to include optional units in areas where our university has relevant capacity, such as green business management, green tourism and green design.

Online learning also opens up possibilities for educational partnerships between institutes. There is also scope for further innovation both in terms of content and method of delivery, to achieve a more student-centred, group-based and active learning approach than we have achieved to date. Nevertheless, our experience demonstrates that Masters-level, distance-learning courses can successfully be developed and implemented, and that there is a demand for them. We hope that the growing need for education in the green economy will encourage the development of similar courses elsewhere.

\section{Acknowledgements}

Many thanks to Molly Scott Cato, James Walmsley and James Derounian for their help and support in developing and implementing this course.

\section{Author Contributions}

Preparation of this manuscript was led by the senior author (Newton), with equal contributions from each of the three coauthors, who checked and revised the text, and contributed material relevant to their individual expertise and experience.

\section{Conflicts of Interest}

The authors declare no conflict of interest. 


\section{References}

1. United Nations Department of Economic and Social Affairs (UNDESA). A Guidebook to the Green Economy. Issue 3: Exploring Green Economy Policies and International Experience with National Strategies; UNDESA: New York, NY, USA, 2012.

2. United Nations Department of Economic and Social Affairs (UNDESA). A Guidebook to the Green Economy. Issue 4: A Guide to International Green Economy Initiatives; UNDESA: New York, NY, USA, 2013.

3. Barbier, E.B. The Green Economy Post Rio+20. Science 2012, 338, 887-888.

4. Allen, C.; Clouth, S. A Guidebook to the Green Economy. Issue 1: Green Economy, Green Growth and Low Carbon Development-History, Definitions and a Guide to Recent Publications; United Nations Division for Sustainable Development, Department of Economic and Social Affairs (UNDESA): New York, NY, USA, 2012.

5. Jones, V. The Green Collar Economy. How One Solution Can Fix Our Two Biggest Problems; Harper Collins: New York, NY, USA, 2009.

6. Newton, A.C.; Cantarello, E. Introduction to the Green Economy; Earthscan: Abingdon, UK, 2014; in press.

7. Makower, J. Strategies for the Green Economy. Opportunities and Challenges in the New World of Business; McGraw Hill: New York, NY, USA, 2009.

8. Esty, D.C.; Winston, A.S. Green to Gold. How Smart Companies Use Environmental Strategy to Innovate, Create Value, and Build Competitive Advantage; John Wiley and Sons: New Jersey, NJ, USA, 2006.

9. Croston, G. 75 Green Businesses you can Start to Make Money and Make a Difference; Entrepreneur Press: Irvine, CA, USA, 2008.

10. Kane, G. The Three Secrets of Green Business. Unlocking Competitive Advantage in a Low Carbon Economy; Earthscan: London, UK, 2010.

11. Weybrecht, G. The Sustainable MBA. The Manager's Guide to Green Business; John Wiley and Sons: Chichester, UK, 2010.

12. Cato, M.S. Green Economics. An Introduction to Theory, Policy and Practice; Earthscan: London, UK, 2009.

13. Chapple, K. Defining the Green Economy: A Primer on Green Economic Development; Center for Community Innovation, University of California: Berkeley, CA, USA, 2008.

14. United Nations Department of Economic and Social Affairs (UNDESA). A Guidebook to the Green Economy. Issue 2: Exploring Green Economy Principles; UNDESA: New York, NY, USA, 2012.

15. Peters, M.A.; Britez, R. Ecopolitics of 'green economy', environmentalism and education. J. Acad. Res. Econ. 2010, 2, 21-36.

16. UNEP. Towards a Green Economy: Pathways to Sustainable Development and Poverty Eradication; UNEP: Geneva, Switzerland, 2011.

17. United Nations Environment Management Group (UNEMG). Working towards a Balanced and Inclusive Green Economy: A United Nations System-Wide Perspective; UNEMG: Geneva, Switzerland, 2011. 
18. International Chamber of Commerce (ICC). Ten Conditions for a Transition toward a "Green Economy”; ICC Task Force on Green Economy: Paris, France, 2011.

19. UNCSD. Report of the United Nations Conference on Sustainable Development; A/CONF.216/16; United Nations: New York, NY, USA, 2012.

20. Newton, A.C. The Green Economy and the Knowledge Economy: Exploring the interface. Int. J. Green Econ. 2011, 5, 231-247.

21. Universities UK. The Funding Environment for Universities. An Assessment; Universities UK: London, UK, 2013.

22. Cedefop. Future Skill Needs for the Green Economy; European Centre for the Development of Vocational Training, Publications Office of the European Union: Luxembourg, Luxembourg, 2009.

23. HM Government. Skills for a Green Economy; HM Government: London, UK, 2011.

24. Wals, A.E.J. Shaping the Education of Tomorrow: 2012 Full-Length Report on the UN Decade of Education for Sustainable Development; UNESCO: Paris, France, 2012.

25. Rogers, P.P.; Jalal, K.F.; Boyd, J.A. An Introduction to Sustainable Development; Earthscan: London, UK, 2008.

26. Blewitt, J. Understanding Sustainable Development; Earthscan: London, UK, 2008.

27. Baker, S. Sustainable Development; Routledge: Abingdon, UK, 2006.

28. Elliott, J.A. An Introduction to Sustainable Development, 3rd ed.; Routledge: London/New York, UK/USA, 2006.

29. UNCTAD. The Green Economy: Trade and Sustainable Development Implications; United Nations: New York, NY, USA, 2010.

30. IUCN. A Guidebook for IUCN's Thematic Programme Area on Greening the World Economy (TPA5); IUCN: Gland, Switzerland, 2010.

31. Green Economy Coalition. The Green Economy Pocket Book; The Green Economy Coalition, IIED: London, UK, 2012.

32. Cato, M.S. Environment and Economy; Routledge: Abingdon, UK, 2011.

33. Dawe, N.K.; Ryan, K.L. The faulty three-legged-stool model of sustainable development. Conserv. Biol. 2003, 17, 1458-1460.

34. Mace, G.M. The Limits to Sustainability Science: Ecological Constraints or Endless Innovation? Plos. Biol. 2012, 10, e1001343. doi:10.1371/journal.pbio.1001343.

35. Holley, K.A. Understanding interdisciplinary challenges and opportunities in higher education. ASHE High. Educ. Rep. 2009, 35, 1-131.

36. Richter, D.M.; Paretti, M. Identifying barriers to and outcomes of interdisciplinarity in the engineering classroom. J. Eng. Educ. 2009, 34, 29-45.

37. Wade, B.H.; Stone, J.H. Overcoming disciplinary and institutional barriers: An interdisciplinary course in economic and sociological perspectives on health issues. J. Econ. Educ. 2010, 41, 71-84.

38. National Academy of Sciences. Facilitating Interdisciplinary Research; The National Academies Press: Washington, DC, USA, 2004.

39. Whitfield, J. An indifference to boundaries. Nature 2008, 451, 872-873. Available online: http://www.nature.com/news/2008/080220/full/451872a.html (accessed on 27 January 2014).

40. McAndrew, P.; Scanlon, E. Open Learning at a Distance: Lessons for Struggling MOOCs. Science 2013, 342, 1450-1451. 
41. Salmon, G. E-Tivities: The Key to Active Online Learning; Taylor \& Francis: London, UK, 2002.

42. Schön, D. The Reflective Practitioner. How Professionals Think in Action; Temple Smith: London, UK, 1983.

43. About. Future Learn. Available online: https://www.futurelearn.com/about (accessed on 28 January 2014).

44. Martin, S.; Martin, M. The 'green' economy and graduate employment. Env. Sci. 2012, 21, 51-54. Available online: http://www.ies-uk.org.uk/resources/green-growth-blueprint-future (accessed on 28 January 2014).

45. Roberts, C.; Daly, M.; Kumar, K.; Perkins, D.; Richards, D.; Garne, D. A longitudinal integrated placement and medical students' intentions to practise rurally. Med. Educ. 2012, 46, 179-191.

46. Andron, S. Rebuilding New Orleans: A Community Field Learning Experience. J. Teach. Soc. Work 2013, 33, 297-307.

47. The Higher Education Academy. Universities and the Green Economy: Graduates for the Future; The Higher Education Academy: York, UK, 2012.

48. Borel-Saladin, J.M.; Turok, I.N. The Green Economy: Incremental Change or Transformation? Environ. Policy Gov. 2013, 23, 209-220.

49. Morrow, K. Rio+20, the green economy and re-orienting sustainable development. Environ. Law Rev. 2012, 14, 279-297.

50. Lander, E. The Green Economy: The Wolf in Sheep's Clothing; Transnational Institute: Amsterdam, The Netherlands, 2011.

51. Waldrop, M.M. Online learning: Campus 2.0. Nature 2013, 495, 160-163.

52. Butin, D.W. What MIT Should Have Done. eLearn Mag. 2012, 6, 3. Available online: http://elearnmag.acm.org/archive.cfm?aid=2263018 (accessed on 28 January 2014).

53. Crow, M.M. Digital learning: Look, then leap. Nature 2013, 499, 275-277.

(C) 2014 by the authors; licensee MDPI, Basel, Switzerland. This article is an open access article distributed under the terms and conditions of the Creative Commons Attribution license (http://creativecommons.org/licenses/by/3.0/). 